\title{
SWEET CHERRY (PRUNUS AVIUM L. SYN. CERASUS AVIUM MOENCH.): A STUDY OF ITS DISTRIBUTION IN LATVIA AND SUPERIOR CLONE SELECTION FOR CHERRY PLANTATIONS FOR WOOD IN LOCAL CLIMATIC CONDITIONS
}

\author{
Mudrìte Daugaviete $^{1, \#}$, Dagnija Lazdina ${ }^{1}$, Daina Feldmane ${ }^{2}$, Dace Treigute ${ }^{1}$, \\ Uldis Daugavietis ${ }^{1}$, Santa Celma ${ }^{1}$, and Austra Zuševica ${ }^{1}$ \\ ${ }^{1}$ Latvian State Forest Research Institute "Silava", 111 Rīgas Str., Salaspils, LV-2169, LATVIA \\ ${ }^{2}$ MZI-APP Institute of Horticulture, Graudu iela 1, Cerini, Krimūnu pagasts, Dobele novads, LV-3701, LATVIA \\ \# Correspondiong author, mudrite.daugaviete@ silava.Iv
}

Communicated by Tālis Gaitnieks

\begin{abstract}
The distribution of sweet cherry (Prunus avium L. syn. Cerasus avium Moench.) in natural woodlands of Latvia was studied. The growth, vitality and stem quality of the first-generation plantations established in Latvia in different agricultural soils using the planting stock of local origin was assessed. In woodlands, sweet cherry is found in 11 Forest Resource Monitoring plots in the administrative regions of Madona, Kuldiga, Alsunga, Saldus, Cirava, and Kazdanga. In the last decade, interest in sweet cherry as a wood producer has increased and plantations with a total area of 21.92 ha were established in 22 localities (Priekule, Kazdanga, Durbe, Talsi, Ventspils, Kuldīga, Tukums, Saldus, Dobele, Bauska, Cēsis, Pārgauja, and Krāslava). Survey was made of sweet cherry plantations established between 1997 and 2019, using both local and foreign origin clonal stock (Danish clone Truust and Swedish clones nos. 9 and 10) in different agricultural soils (typic sod-calcareous soil; sod-podzolic soil; stagnogley sod-podzolic soil) in the districts of Priekule, Kuldiga, Dobele, Bauska, Kegums, and Smiltene. In plantation forests with optimal growing conditions (typical sod-calcareous soil; $\mathrm{pH} 6$ to 7), 22-year-old sweet cherries of local origin had height $(H)$ of $15.1 \mathrm{~m}$, the diameter at breast hight $(D B H)-16.4 \mathrm{~cm}$ and stem volume $157.7 \mathrm{dm}^{3}$ on average. The maximum $\mathrm{H}$ and $\mathrm{DBH}$ observed for the largest trees reached $17.6 \mathrm{~m}$ and $25.3 \mathrm{~cm}$, respectively. The Danish clone Truust and the Swedish clones nos. 9 and 10 of sweet cherries were promising for growing in Latvian climatic conditions. Selection of perspective clones for establishment of second-generation plantations was made for sweet cherries of local origin.
\end{abstract}

Keywords: wild cherry, native clones and genotypes, course of growth, stem quality.

\section{INTRODUCTION}

In Europe, plantation cultivation of sweet cherry (Prunus avium L. syn. Cerasus avium Moench) as one of the major tree species producing hard-textured wood started in the 1950s (Ducci et al., 2013). Until now, research and development of sweet cherry has considered the following aspects: growth in various macro- and micro-climatical conditions, optimal cultivation methods for producing wood of desired quality, the selection of suitable clones not only for stem quality, but also for visually appealing wood colour and shading, the control of pests and diseases, and methods of clonal propagation (Pryor, 1988; Ducci and Santi, 1998; Martinsson, 2001; Russel, 2003; Zianis et al., 2005; Hubert and Cundall, 2006; Berti et al., 2007; Hemedry et al., 2008; Hemery et al., 2010; Nocetti et al., 2010; Petrokas, 2010; Hawe and Short, 2016; Welk et al., 2016). Woodworking experts rank cherry wood next to walnut for its quality and durability (Ducci et al. 2013). The morphological traits of sweet cherry with important ecological roles also have been studied: blossoms, fruit, crown biomass, woody biomass, litter, attraction of bees and bumblebees, birds, mammals, and conservation of biological diversity (Breibach et al., 2010; Welk et al., 2013). 
Due to climate warming, interest in sweet cherry cultivation in plantation forests, especially in agroforestry systems, is increasing also in Northern Europe (McEwan et al., 2020).

Biology, ecology and genetics. As a Prunoideae subgenus of the Rosaceae genus, sweet cherry (Prunus avium L. syn. Cerasus avium (L.) Moench; syn. Prunus sylvestris Ray) was first described in 1596 (Praciak et al., 2013). However, the historical data show that it was used for food already in the $5^{\text {th }}-4^{\text {th }}$ millenium BC (Turnbull, 2003; Ruisa, 2015). In 800 BC, cherries were widely cultivated in Asia Minor and later in Greece (Rushorth, 1999). In Switzerland, near Lake Constance, cherry stones were found in archeologic exavations of a settlement from the period of $1^{\text {st }}-3^{\text {rd }}$ century AD (Pollmann et al., 2005). Interesting historical data about the spread of sweet cherry in Northern Europe have been published. The species was brought to Sweden by the Vikings or Christian monks in about 1000 AD (Turnbull, 2009; Martinson, 2001). However, there are findings also about earlier cherry distribution - macroremains of cherries were found in archeologic exavations of a Mesolithic settlement in southern Sweden from the period of 6700-6000 BC (Regnell, 2012).

Sweet cherry, also known as wild cherry or gean, originated south-east of Europe. Its natural range stretches over vast areas in western Asia (Anatolia, Maghreb), the Caucasus, northern Iran, and the western Himalayan region. This tree species is found also in Morocco and Tunisia, and in the northern direction - to the British Isles and as far as the Trondheim Fjords in Norway. Sweet cherry is widely cultivated in other regions as well and it has naturalised in North America and Australia (Russel, 2003; Welk et al., 2016). Although the central regions of Poland are considered as the northern boundary of the natural range of sweet cherry, it has been found in the forests of southern Sweden and Norway. These provenances strongly differ in the time of budbursting, blossoming, and fruit ripening (Martinsons, 2001).

Sweet cherry is a broadleaved tree that reaches up to 15 to $20 \mathrm{~m}$ in height, with a stem up to $90 \mathrm{~cm}$ in diameter (Ducci et al., 2013). Its lifespan normally does not exceed 70 to 80 years. Young trees have distinct apical dominance with a straight stem and a symmetrical conical crown, which becomes rounded to irregular in older trees.

Sweet cherry is a self-incompatible species. This property is regulated by multi-allelic single $\mathrm{S}$ locus with gametophytic action (Ducci et al., 2013). Cross-pollination achieved by honeybees, bumblebees and other insects is necessary for flowering and seed development. Sweet cherries in forest stands can only regenerate in places where there are abundant populations of honeybees, bumblebees and other pollinators. Sweet cherry spread is closely related also with the activities of birds, mammals and humans in mutual relationships. Many species of birds and mammals feed on the fruit of sweet cherry, digesting the fruit pulp and dispersing its seeds by endozoochory. Some rodents and birds can crack the fruit endocarp to eat its seed. In Europe, the sites with fertile soils that are suitable for cherry growth in the wild mostly are used for field crops. Thus, the role of humans in cherry propagation, growing and preservation is increasing.

Besides fresh fruit consumption, there are various ways for use of different parts of cherry trees, which all are beneficial for humans. In woodworking, the solid red-brownish wood of sweet cherry is a hard-textured wood used for making furniture and musical instruments (Ducci et al., 2013).

In North America, sweet cherry is used as fuel-wood for smoke-drying foodstuffs, especially meat, proving a unique flavour. Cherry wood chips used for salmon smoking have an inhibitory effect on food toxicants $(\mathrm{Oz}, 2020)$. Historical data show that ancient Greeks used not only sweet cherry fruit but also its wood and resin as a remedy for coughs (Ruisa, 2015). The slime or resin from cherry bark wounds is aromatic and can be chewed as chewing gum (Ducci et al., 2013). Fruit stalks can be used to obtain a drug with astringent, anti-cough and diuretic effect (Praciak et al., 2013).

Sweet cherry as timber producer. In Europe, sweet cherry is found mainly in the woodlands in a mixture with other tree species and in cultivated areas. Nowadays, the largest European natural woodlands comprising sweet cherry are in Poland — 44000 ha, followed by Germany - 38000 ha, France - 24200 ha, Italy — 23000 ha, and Spain 13500 ha, but the the largest plantations of sweet cherry are in Italy - 60000 ha, and Spain — 8000 ha (Ducci et al., 2013; Welk et al., 2016). According to research data, the largest potential areas for cultivating of sweet cherry are in Italy -2.57 million ha, in Slovakia -1.15 million ha, and in Belgium - 156000 ha.

In natural mixed forests, the proportion of sweet cherry is not particularly high. Still, this species has been increasingly cultivated for its valuable wood since the last century (Savill, 2003; Ducci et al., 2013; Welk et al., 2016). In European countries, sweet cherry forest stands after cutting mostly are regenerated by planting. On average, about $43.5 \%$ sweet cherry stands have been replanted in Europe, with a higher proportion in Germany - about $74.2 \%$. Sweet cherry may be grown both in pure stands and in a mixture with other tree species, at densities of $277(6 \times 6 \mathrm{~m})$ to $6000(1 \times 1.5 \mathrm{~m})$ stems/ha. Branch pruning is recommended in sparse stands while side shading promotes selfpruning in dense plantations (Pakenham, 2005; Short and Radford, 2008; Stojecova and Kupka, 2009; Ducci et al., 2013).

Sweet cherry grows best in fresh mineral-rich sandy and calcareous soils. In forest stands, its height varies between 15 to $20 \mathrm{~m}$ and 30 to $35 \mathrm{~m}$ with average stem diameter of 40 to $70(80) \mathrm{cm}$, depending on soil fertility. The stems are slim with a well-shaped crown.

Sweet cherry grows quite untill age of 40 years. Annual growth declines by the age of 50 to 60 years. Therefore, the optimum felling age for cherry is 60 to 80 years (Pryor, 1988; Kerr and Evans, 1993; Pakenham, 2005; Short and 
Radford, 2008; Hein and Spiecker, 2009; Stojecova and Kupka, 2009; Ducci et al., 2013; Loewe et al., 2013; Savill, 2013).

In several European countries (Belgium, Germany, Italy, France, Czech Republic, Slovakia, Sweden, etc.), the productivity of European or sweet cherry has been assessed using special growth tables, which are widely used for determining the optimal economic maturity of a cherry stand in terms of its standing volume and the optimum felling age (Zianis et al., 2005).

Scientists believe that sweet cherry is a promising tree species for the future. It has already shown excellent performance in intensively managed plantations with appropriate tending, branch pruning, fertilisation, etc. The wood of sweet cherry is considered to be highly valuable throughout the world. It is fairly hard, flexible, easily workable, and easy to polish, stain and varnish. It has been marketed as roundwood, sawn wood and cut or sliced veneer. Sweet cherry timber is mainly used in the furniture industry instead of mahogany and other noble hardwoods. In veneer production, maple is predominantly used (comparing to other European tree species), followed by sweet cherry and other hardwoods like ash, oak, etc.

The mechanical strength and durability of sweet cherry timber are also importance factors to consider in the furniture industry. In international markets, the price of sweet cherry wood ranges from 600 to $1200 \mathrm{EUR} / \mathrm{m}^{3}$. Especially highquality material may reach a price of up to $3000 \mathrm{EUR} / \mathrm{m}^{3}$ and more (Nocetti et al., 2017). Compared with the 1930s, the price of sweet cherry timber has more than tripled. For pricing of sweet cherry wood products, factors like pale yellowish shading of wood and tree ring width (up to $1 \mathrm{~cm}$ ) also are important (Ducci et al., 2013; Nocetti et al., 2017).

Along with its economic value (wood), the remarkable contribution of sweet cherry to biodiversity (nectar, food resource for birds, sweet litter) is of particular importance (Breibach et al., 2010; Morhart et al., 2016; Welk et al., 2016).

Over the last decade, even greater attention has been paid to the development of sweet cherry plantation cultivation methods, with a focus on two major characteristics of forest products — wood quality and timber dimensions. These goals can be achieved by selecting the most valuable clones for breeding planting stock, choosing the most suitable sites for establishing plantations, timely tending of trees already in juvenile stage followed by respacing and pre-commercial thinnings (Pakenham, 2005; Hemedry et al, 2008; Loewe et al., 2013; Payn et al., 2015; Hawe and Short, 2016; Welk et al., 2016).

In the early 1970 s, sweet cherry was considered as a tree species typical of Central Europe. However, extensive studies on sweet cherry breeding studies for wood production are under way also in Sweden, Norway, Denmark, and Canada. These countries have obtained sweet cherry prove- nances, which under certain conditions are rather fastgrowing, at the same time providing raw material of premium-quality for the furniture industry, particularly for veneer products. Second and third generation seed orchards developed in these countries produce high quality seeds. Sweet cherry seed orchards have been established also in the Czech Republic, Germany and France (Lacis et al., 2009; Nocetti et al., 2010; Jarni et al., 2012; De Rogatis et al., 2013; Ducci et al., 2013). In recent years, in Europe and elsewhere, scientists are stepping up the process of selecting and propagating the sweet cherry provenances most suitable for plantation cultivation (Russel, 2003; Hubert and Cundall, 2006; Lacis et al., 2009; Nocetti et al., 2017; Velioglu et al., 2020).

Sweet cherry is highly susceptible to the Phytophtora fungus, which significantly affects wood quality. Availability of disease-resistant clones of this species is of paramount importance. From the 1970s onwards, the scientists have conducted immense work in selecting and propagating stable and resistant sweet cherry clones, particularly in central, western, and southern Europe (Poland, Czech Republic, Slovakia, Germany, Belgium, the Netherlands, France, the UK, Italy, Switzerland, Romania, Bulgaria, Hungary, Spain, and Portugal), but also in the Nordic countries (Denmark, Sweden, and Norway) and the USA and Canada (Pryor 1988; Ducci et al., 2013; Hawe and Short 2016; Welk et al., 2016).

Researchers have identified several other factors adversely affecting sweet cherry quality in forest stands: natural seed dispersal by birds and other animal from the areas with differing ecological conditions, and also seed harvesting for propagation from very small stands or even individual trees (Russel, 2003).

Actions suggested for improving the quality of cherry stands:

- preventing hybridisation between superior trees and low-quality cherry clones;

- developing suitable pest and disease control means and methods;

- selection of promising cherry clones and establishing plantations of mother plants;

- no cultivation of the planting stock from seeds, giving preference to rooting of cuttings and in vitro techniques.

Situation in Latvia. In Latvia, sweet cherry as a forest tree species is becoming quite common as individual trees or in small groups. Still, there is insufficient knowledge of the frost resistance of this species, its growth rate, which are the criteria for clone selection for cultivating stock that would yield high quality wood. The Latvian dendrologists V. Lange, A. Mauriņš, and A. Zvirgzds (Lange et al., 1978) have indentified several fully acclimatised sweet cherry populations (Dobele, Ēdole, Saldus, Patkule), which are believed to have been introduced between the $11^{\text {th }}$ and $15^{\text {th }}$ 
centuries, when German landowners imported European wild cherry as a fruit tree for planting in their estates. This species spread mainly in the western part of present-day Latvia (Dobele, Kuldīga, Talsi, Liepaja, Saldus, Ventspils, Tukums), and in some places in the central and eastern regions (Rīga, Cēsis, Madona, etc.) (Keris, 1997; Mangalis, 1998; Daugaviete et al., 2002; Ruisa, 2015).

Because of the global warming (air temperature is expected to rise by $2{ }^{\circ} \mathrm{C}$ in the coming 50 years), the forecasted climatic conditions in Latvia will become more suitable for sweet cherry growth, increasing the spread of this species also in the country's cental and eastern regions where the climate is more continental. Therefore, the selection of superior sweet cherry genotypes and propagation of the clonal stock to establish productive plantation forests or mixed plantings is of great importance (Daugaviete et al., 2017).

To clarify the prospects for cultivating of sweet cherry in Latvia, research was launched within the framework of the Phare project "Technical Support for the Development of Private Forestry in Latvia" in 1995 when first sweet cherry forest plantations, with a total area of about 10 ha were established in both the western (Liepāja, Kuldīga, Dobele), central (Ogre) and estern (Madona, Gulbene) regions of Latvia (Daugaviete et al., 2002; Daugaviete, 2003; Daugaviete, 2006; Daugaviete, 2009; Daugaviete et al., 2017). The seed material for the planting material was obtained from the Institute of Horticulture in Dobele from sweet cherry seed trees collected in woodlands of the western and southern regions of Latvia by the prominent Latvian breeder P. Upitis. This explains why the material planted in the central and eastern parts of Latvia (Gulbene and Madona) was not sufficiently frost resistant for the climatic conditions there. In order to successfully continue the work in progress and select high-quality sweet cherry provenances suitable for different climatic regions of Latvia, an inventory of cherry stands and individual trees was carried out, collecting seeds from the elite trees for growing the planting material. In the framework of the project TOP 01-28 in 2001, a forest stand inventory in the western regions (Kuldīga and Talsi) was launched, where individual superior sweet cherry stands and elite trees were identified (Daugaviete et al., 2002). Quite frequently individual trees 20 to $22 \mathrm{~m}$ high and higher were encountered. However, there were few trees with a completely intact crown, implying that sweet cherry was used mainly for obtaining fruit and not wood. The tops of trees were repeatedly cut to lower the crown height, such that it was often impossible to determine the exact tree height. The canopies were trained to stimulate fruitingwood formation and fruit-bearing. There were considerable differences between individual sweet cherry elite trees in flowering and fruit ripening time, as well as in fruit colour, also for trees in the same stand (Daugaviete et al., 2006).

Sweet cherry easily regenerates naturally, creating a thick grove. Yet, because of wildlife damage (mainly Artiodactyla), the growth is highly uneven and only individual trees reach maturity. Such a situation is quite common in abandoned farmlands overgrown by forest, where sweet cherry is found in a mixture with grey alder, birch, oak, maple, etc. (Daugaviete et al., 2002). In 2006-2007, 69 seed trees were selected, which met the criteria for high-quality sweet cherry specimens: strong, vital and straight stem with no wounds, cracks or signs of rot, and fine branches with a wide branching angle (Daugaviete et al., 2006).

Local residents have long used cherry timber for interior finishing, and for making tables, chairs, cabinets, etc. Survey of the regions of cherry distribution in Latvia showed that the use of boards of cherry logs in the making and finishing of furniture is a common practice in western area (Saldus and Liepāja districts).

Experts of the Wood Chemistry Institute analysed the physico-mechanical properties of Latvia's sweet cherry timber and found that its density was higher than that of wood of Central European origin. This implies higher competiveness of cherry timber products of Latvian origin on the world market (Daugaviete et al., 2003; Pavlovičs et al., 2007; Pavlovičs, 2011).

Currently, researchers of the Latvian Forest Research Institute "Silava" (LFRI "Silava") have focus on the sweet cherry plantation forests (total area 21.92 ha) established since 1997 throughout the country (Alsunga, Bauska, Brocēni, Cēsis, Dobele, Kazdanga, Krāslava, Kuldīga, Pārgauja, Priekule, Talsi, Tukums, and Ventstpils). Survey of wild cherry growth was continued in the following municipalities: Talsi/Baltgale, Smiltene/Vecmezieli, Kegums/ Rembate, Bauska/İslīce, and Dobele/Auri (Table 1, Fig. 1).

The research conducted thus far and Forest Resources Monitoring data show that sweet cherry has emerged naturally in woodlands of the following regions of Latvia: a) Kurzeme (west); the municipalities of Talsi, Saldus, Alsungas, Aizpute, Durbe, and Brocēni; b) Zemgale (central regions) Tukums, Jaupils, Dobele, and Bauska; and c) Vidzeme (north-east) — Beverīna, Priekuḷi, Līgatne, Jaunpiebalga, Madona, Pārgauja (Daugaviete, 2006;

http://www.silava.lv/petijumi/nacionlais-mea-monitorings.a spx).

Sweet cherry as admixed species has preserved mainly in private forest holdings in the Aegopodiosa forest type (Gr), together with species like grey alder, ash, oak, and lime (Daugaviete, 2006). Thick self-sown groves of sweet cherry are also quite common in abandoned farmlands and on ditch slopes overgrowing with shrubs and trees like grey alder.

Data analyses and estimates show that in the climatic conditions of the country's southern, south-western and central regions, whose northern boundary is the line SaulkrastiKegums-Bauska, sweet cherry may by the age of a) 10 , b) 20 , c) 30 , d) 40 , and e) 50 years, reach the following dimensions: a) $\mathrm{H}_{\mathrm{avg}}=6$ to $8 \mathrm{~m} ; \mathrm{DBH}=8$ to $10 \mathrm{~cm}$; b) $\mathrm{H}_{\mathrm{avg}}=$ 12 to $15 \mathrm{~m}, \mathrm{DBH}=15$ to $18 \mathrm{~cm}$; c) $\mathrm{H}_{\mathrm{avg}}=16$ to $20 \mathrm{~m}$, $\mathrm{DBH}=18$ to $22 \mathrm{~cm}$; d) $\mathrm{H}_{\mathrm{avg}}=22$ to $23 \mathrm{~m}, \mathrm{DBH}=25$ to 
Table 1. Sweet cherry plantations in Latvia (www.vmd.gov.lv)

\begin{tabular}{|c|c|c|c|c|}
\hline Municipality & Parish & Coordinates & Area, ha & $\begin{array}{c}\text { Timber } \\
\text { volume, } \mathrm{m}^{3}\end{array}$ \\
\hline Priekule & Priekule & $\begin{array}{l}56.391388 \\
21.676388\end{array}$ & 1.5 & 87 \\
\hline Talsi & Balgale & $\begin{array}{l}57.147222 \\
22.908611\end{array}$ & 1.53 & 66 \\
\hline Talsi & Lauciena & $\begin{array}{l}57.22096 \\
27.78055\end{array}$ & 0.21 & 5 \\
\hline Talsi & Lauciena & $\begin{array}{l}57.20171 \\
22.78745\end{array}$ & 1.00 & 186 \\
\hline Tukums & Sēme & $\begin{array}{l}57.04905 \\
23.13172\end{array}$ & 0.35 & 12 \\
\hline Tukums & Rūmene & $\begin{array}{l}57.04905 \\
22.13172\end{array}$ & 0.50 & 35 \\
\hline Tukums & Tume & $\begin{array}{l}56.93442 \\
23.10019\end{array}$ & 0.33 & 32 \\
\hline Ventspils & Ugāle & $\begin{array}{l}57.27366 \\
22.00347\end{array}$ & 3.01 & 144 \\
\hline Kazdanga & Kazdanga & $\begin{array}{l}56.73418 \\
21.73561\end{array}$ & 0.10 & 4 \\
\hline Alsunga & Alsunga & $\begin{array}{l}56.99282 \\
21.68517\end{array}$ & 0.25 & 6 \\
\hline Auce & Vìtiņi & $\begin{array}{l}56.43424 \\
22.91321\end{array}$ & 0.10 & 3 \\
\hline Bauska & Dāviņi & $\begin{array}{l}56.47387 \\
24.38731\end{array}$ & 4.82 & 289 \\
\hline Bauska & İslīce & $\begin{array}{l}56.31790 \\
24.18739\end{array}$ & 1.0 & 78 \\
\hline Broceni & Remte & $\begin{array}{l}56.74954 \\
22.70065\end{array}$ & 1.19 & 36 \\
\hline Cēsis & Vaive & $\begin{array}{l}57.22718 \\
25.32478\end{array}$ & 1.00 & 7 \\
\hline Dobele & Auri & $\begin{array}{l}56.59301 \\
23.25590\end{array}$ & 1.81 & 54 \\
\hline Durbe & Vecpils & $\begin{array}{l}56.87000 \\
24.35140\end{array}$ & 0.18 & 10 \\
\hline Krāslavas & Izvalta & $\begin{array}{l}55.96191 \\
27.02619\end{array}$ & 0.35 & 42 \\
\hline Kuldīga & Edole & $\begin{array}{l}56.99707 \\
21.68721\end{array}$ & 1.00 & 75 \\
\hline Kuldīga & Padure & $\begin{array}{l}57.05083 \\
21.76805\end{array}$ & 0.41 & 28 \\
\hline Kuldīga & Turlava & $\begin{array}{l}5682268 \\
21.76254\end{array}$ & 1.08 & 59 \\
\hline Pārgauja & Straupe & $\begin{array}{l}57.35347 \\
24.97783\end{array}$ & 0.11 & 13 \\
\hline Total, ha & & & 21.92 & \\
\hline
\end{tabular}

$35 \mathrm{~cm}$; e) $\mathrm{H}_{\mathrm{avg}}=23$ to $25 \mathrm{~m}, \mathrm{DBH}=35$ to $45 \mathrm{~cm}$, respectively (Daugaviete et al., 2002).

The aims of the study were:

- to examine local sweet cherry provenances and select promising genotypes for high-quality stem for wood production,

- to assess the growth of sweet cherry in existing plantations and summarise information of their origin and growing conditions, to ensure sustainable cultivation of sweet cherry for timber in Latvia.

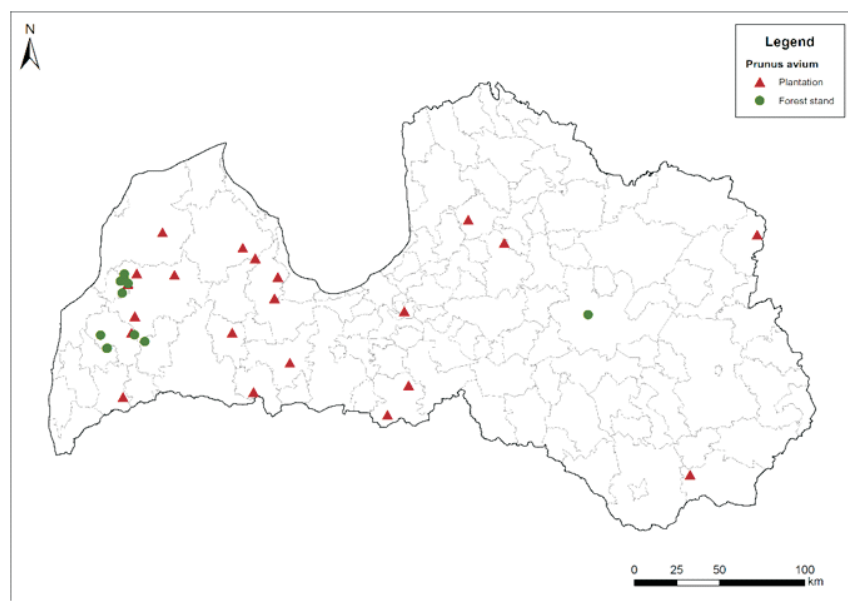

Fig. 1. The occurrence of sweet cherry in natural forests in forest resource monitoring plots $(\mathrm{O})$ and plantations $(\nabla)$.

\section{MATERIALS AND METHODS}

To meet the aims, the following studies were carried out:

- analysis of the growth rates of sweet cherry in the existing trial plantations in the municipalities of Priekule, Kuldīga, Talsi, Bauska, Dobele and Smiltene, considering the origin of planting material and growing conditions (Table 2, Fig 2),

- selection of superior sweet cherry genotypes perspective for timber production and growing in an agroforestry system, from local cherry provenances found in various regions in Latvia and grown in various environments (in forest stands, plantation forest and fruit-growing orchards).

For analysis of the growth rates of sweet cherry, information on soil type, planting density and origin of planting material was summarised. Measurement was made of tree height, $\mathrm{H}, \mathrm{m}$; stem diameter at breast hight, $\mathrm{DBH}\left(\mathrm{D}_{1,3}\right)$, $\mathrm{cm}$; and height of the branchless part of stem, cm. Increment boring at breast height was used to determine the current annual increment over the last five years. Tree ring width was determined using Win Dendro 2018 software.

Timber volume was calculated for each plantation and the mean tree volume of mean tree as follows (Liepa, 1996).

The volume of individual stems was determined according to the formula (Liepa, 1996):

$v=\psi L^{\alpha} D^{\beta l g L+\varphi}$

where:

$v$ - stem volume over bark, $\mathrm{m}^{3}$;

$L$ - stem length, m;

$D$ - DBH over bark, cm;

$\psi, \alpha, \beta . \varphi$ - factors specific for the respective tree species. For calculating the cherry stem volume, factors for common 
Table 2. Characteristics of sweet cherry trial plantations

\begin{tabular}{|c|c|c|c|c|c|c|c|c|}
\hline $\begin{array}{l}\text { Site location/region- } \\
\text { property - origin }\end{array}$ & Location & $\begin{array}{l}\text { Year of planting, } \\
\text { planting design }\end{array}$ & Soil type & $\begin{array}{l}\text { Age yrs/n } \\
\text { trees ha }^{-1}\end{array}$ & $\mathrm{D}, \mathrm{cm}$ & $\mathrm{H}, \mathrm{m}$ & $\begin{array}{c}\mathrm{V}, \mathrm{dm}^{3} / \text { aver- } \\
\text { age tree }\end{array}$ & $\mathrm{V}, \mathrm{m}^{3} \mathrm{ha}^{-1}$ \\
\hline $\begin{array}{l}\text { Priekule/ Ozolbunči - } \\
\text { Priek/Ozolb } \\
\text { Local }\end{array}$ & $\begin{array}{l}56.39138 \\
21.67638\end{array}$ & $\begin{array}{c}1997 \\
2000 \text { tree ha }^{-1} \\
(2 \times 2.5 \mathrm{~m})\end{array}$ & TSC & $22 / 984$ & $16.4 \pm 4.9$ & $15.1 \pm 1.4$ & 157.7 & 155.2 \\
\hline $\begin{array}{l}\text { Kuldīga/ Rumnieki - } \\
\text { Kuld/Rumn - Local }\end{array}$ & $\begin{array}{l}57.05083 \\
21.76805\end{array}$ & $\begin{array}{c}19973300 \text { tree ha }^{-1}, \\
(1.5 \times 2 \mathrm{~m})\end{array}$ & SSP & $22 / 1543$ & $12.5 \pm 3.5$ & $12.0 \pm 1.3$ & 84.6 & 106.0 \\
\hline $\begin{array}{l}\text { Smiltene/ Vecmežiel̦i - } \\
\text { Smilt/Vecm Local }\end{array}$ & $\begin{array}{l}59.62008 \\
21.65124\end{array}$ & $\begin{array}{c}20022500 \text { tree ha }^{-1}, \\
(2 \times 2 \mathrm{~m})\end{array}$ & SSP & $18 / 1898$ & $11.2 \pm 3.6$ & $9.8 \pm 1.3$ & 58.6 & 111.2 \\
\hline $\begin{array}{l}\text { Kegums/ Rembate - } \\
\text { Keg/RembLocal }\end{array}$ & & 2500 tree ha $^{-1},(2 \times 2 \mathrm{~m})$ & SSP & $18 / 800$ & $13.2 \pm 2.6$ & $13.8 \pm 1.6$ & 103.5 & 51.3 \\
\hline $\begin{array}{l}\text { Talsi/ Zeltini - Tals/Zelt } \\
\text { Local }\end{array}$ & $\begin{array}{l}57.14722 \\
22.90861\end{array}$ & $\begin{array}{c}2003 \\
10000 \text { tree ha }^{-1},(1 \times 1 \mathrm{~m})\end{array}$ & SP & $17 / 3386$ & $10.1 \pm 2,9$ & $10.1 \pm 1.2$ & 51.1 & 173.0 \\
\hline $\begin{array}{l}\text { Bauska/ Ziedini - Bausk/Zied } \\
\text { Danish clone mix Truust } 791\end{array}$ & $\begin{array}{l}56.31790 \\
24.18739\end{array}$ & $\begin{array}{c}2011 \\
2000 \text { tree } \text { ha }^{-1},(2 \times 2.5 \mathrm{~m})\end{array}$ & SP & $9 / 2500$ & $10.6 \pm 2.0$ & $7.9 \pm 0.6$ & 50.9 & 127.2 \\
\hline $\begin{array}{l}\text { Bauska/ Ziedini - Bausk/Zied } \\
\text { Swedish clones No } 9 \text { and } 10\end{array}$ & $\begin{array}{l}56.31790 \\
24.18739\end{array}$ & $\begin{array}{c}20132000 \text { tree ha }^{-1} \\
(2 \times 2.5 \mathrm{~m})\end{array}$ & SP & $7 / 2500$ & $7.5 \pm 2.5$ & $5.2 \pm 1.2$ & 17.6 & 43.9 \\
\hline $\begin{array}{l}\text { Dobele/ Ezernieki - } \\
\text { Dob/Ezern Swedish clones } \\
\text { No } 9 \text { and } 10\end{array}$ & $\begin{array}{l}56.59301 \\
23.25590\end{array}$ & 2000 tree ha $^{-1},(2 \times 2.5 \mathrm{~m})$ & TSC & $7 / 2000$ & $3.0 \pm 1.2$ & $3.6 \pm 3.1$ & 2.1 & 3.4 \\
\hline
\end{tabular}

* TSC, typical sod-calcareous soil; SP-sod-podzolic soil; SSP-Stagnogley sod-podzolic soil

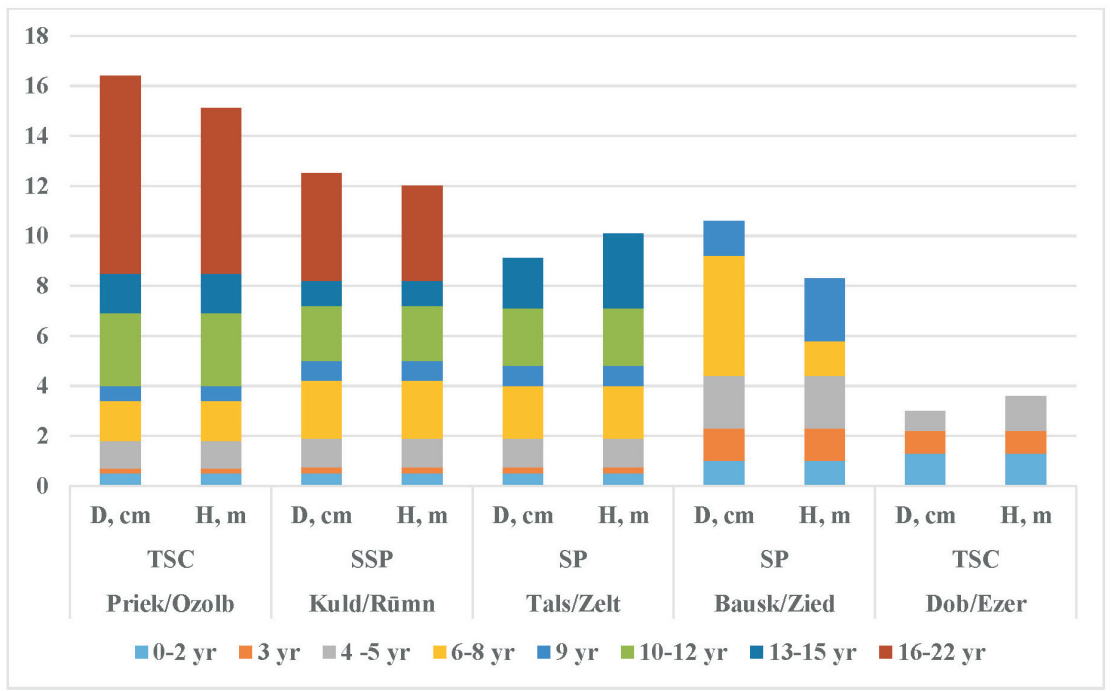

Fig. 2. Cumulative stem diameter (D) and tree height (H) growth for different sweet cherry clones in 7-22 year plantations, $\mathrm{cm}$. alder were used: $\Psi=0.7950 \times 10^{-4} ; \alpha=0.77095 ; \beta=$ 0.13505; $\varphi=1.80715$ (Liepa, 1996).

For stem quality assessment, sweet cherries were evaluated in seven existing plantations. The following indices were used: stem crookedness ( 1 - straight; 2 - slightly crooked; 3 - strongly crooked), multiple tops, distinct single apex, ingrown stems below the height $2 \mathrm{~m}$, branchiness below the height $2 \mathrm{~m}$. The percentage of stems of different qualities was calculated.

The selection of superior clones and genotypes for timber production was based on the assessment of stem quality and dendrometric data. Additionally, preliminar evaluation of fruit quality was done for genotypes promising for agroforestry systems, by determination of fruit mass.

\section{RESULTS}

Growth rate. The first sweet cherry plantations were established within the Phare project at the Priek/Ozolb and Kuld/Rumn trial sites, using seedlings from the Institute of Horticulture in Dobele (Daugaviete et al., 2017).

Between 2001 and 2019, the LFRI "Silava" specialists assessed the sweet cherry plantations created by private landowners in a number of municipalities in the western, central and eastern parts of the country (Talsi/Balgale/Zeltini; Bauska/Īslīce/Ziediṇi; Smiltene/Smiltene Vecmežieḷi).

The planting material used for the Tals/Zell and Smilt/Vecm sites was obtained from individual superior cherry seed trees in the tree nurseries I.U. "Bērzi" and Ltd. Olaine. 
After 2007, the LVM division "Sēklas un stādi" (Latvian State Forest Company, division Seeds and Plants) used the Swedish origin clones No. 9 and 10 for cultivating the planting stock used in the Dob/Ezer trial site.

After 2010, a cherry plantation was established at the Baus/Zied site, using the planting material derived from the Danish clone Truust (Danish Forest and Landscape Research Institute, Certificate of Origin No. DK/A3352).

Data on the growth rates of sweet cherry in 7 to 22 -year-old plantations are summarised in Table 2, Fig. 2. The average height of 22-year-old sweet cherry trees in the plantations on dry mineral soils was $12.0-15.1 \mathrm{~m}$ and the average DBH was 12.5-16.4 cm (Fig. 2). The best vitality and fastest growth were observed for cherries on mineral-rich soils with a neutral or alkaline reaction ( $\mathrm{pH} 6$ to 7 and more). In relief depressions and sites with wet soils and excess surface waters, sweet cherry suffered from spring night frosts and lagged behind in productivity.

Danish clone Truust 791 and the Swedish clones No. 9 and 10 showed good performance in trial plantations, reaching breast height already in the second or third year after planting. At the age of nine years, trees of the Truust 791 clone (Baus/Zied site) had mean height $\mathrm{Hv}=7.9 \mathrm{~m}$ and $\mathrm{DBH}=$ $10.6 \mathrm{~cm}$. It should be noted that these plantations were also carefully tended, which has promoted tree growth.

Of the plantations established using the stock of local origin, the best performance was shown in the Priek/Ozolb plantation located in south-west Latvia on soddy carbonate soil $(\mathrm{pH}=6.5)$. At the age of 22 years, the average growth rate indices were: $\mathrm{H}_{\mathrm{v}}=15.1 \mathrm{~m}$ and $\mathrm{D}_{\mathrm{v}}=16.4 \mathrm{~cm}$, $\mathrm{v}=57.7 \mathrm{dm}^{3}$ (Table 2).

The field data showed that in sweet cherry plantations, the optimal initial density of stocking ranged from 1600 (planting pattern $2 \times 3 \mathrm{~m})$ to $2000(2 \times 2.5 \mathrm{~m})$ trees/ha. In such situations the canopy closure takes place in the $5^{\text {th }}$ to $6^{\text {th }}$ year after planting. It should be noted that no self-pruning of branches was observed in the 22-year-old plantations.

High mortality of trees and low productivity of wood were observed in overstocked sweet cherry plantations (up to 10000 trees/ha). At the Tals/Zelt site only $56 \%$ of the initially planted stock had survived till the age of 12 years, and only $33 \%$ till the age of 17 years (Table 2) (Daugaviete et al. 2017).

Stem quality. In order to obtain top quality cherry stems, stem formation should be started timely. Straight branchless stems were found in trial plantations where branches had been accordingly pruned and competing tops removed starting from the first growing years (Table 3).

On average, a distinctly straight apex was observed only for 65 to $70 \%$ of the cherry trees originated from local seed trees. This means that in order to obtain higher quality stems, it is necessary to select elite trees and propagate the
Table 3. Stem quality of 22-year-old sweet cherry stands

\begin{tabular}{|l|c|c|c|c|c|c|}
\hline $\begin{array}{l}\text { Priek/Ozolb } \\
22 \text { yrs }\end{array}$ & 10 & 85 & 40 & 60 & 10 & 75 \\
\hline $\begin{array}{l}\text { Kuld/Rumn } \\
22 \text { yrs, }\end{array}$ & no & 75 & 35 & 65 & 25 & $\begin{array}{c}90 \text { (separate } \\
\text { branches) }\end{array}$ \\
\hline $\begin{array}{l}\text { Smilt/Vecm } \\
18 \text { yrs }\end{array}$ & no & 85 & 30 & 70 & 20 & 75 \\
\hline $\begin{array}{l}\text { Keg/Remb } \\
18 \text { yrs }\end{array}$ & 20 & 60 & 40 & 70 & 25 & 70 \\
\hline $\begin{array}{l}\text { Tals/Zelt } \\
12 \text { yrs }\end{array}$ & no & 75 & 35 & 65 & 25 & 75 \\
\hline $\begin{array}{l}\text { Bausk/Zied } \\
9 \text { yrs } \\
\text { Truust clone }\end{array}$ & no & 100 & no & 100 & Indistinct & Pruned \\
\hline $\begin{array}{l}\text { Dob/Ezer } \\
7 \text { yrs }\end{array}$ & no & 95 & 5 & 95 & Indistinct & 100 \\
\hline
\end{tabular}

clonal stock by rooting of cuttings or using in vitro techniques.

Superior clone selection. In 2020, inventory of individual sweet cherry clones was launched in private forersts of the Alsunga municipality, including a survey of the existing first-generation sweet cherry plantations, selecting the trees most suitable for vegetative propagation and harvesting the tree parts suitable for it. In cherry plantations, 3 to 11 superior clones were selected and cuttings were collected for further propagation both by rooting and by in vitro techniques (Table 4).

At the Institute of Horticulture in Dobele (LatHort), several vigorous local sweet cherry varieties showed regular yielding and a resistance of flowers to spring frosts -3 to $-4{ }^{\circ} \mathrm{C}$ at the end of flowering (Feldmane, 2020). Especially vigorous and vital genotypes were selected for further investigation and propagation in the cherry genetic resource plantation of LatHort, where trees were grown for fruit production and their height and branching was strongly changed by pruning. Because of their fruits suitable for food and other food industry products, these genotypes may be propagated for use in agroforestry.

Table 4. Selection of superior sweet cherry clones in forest stands and plantations

\begin{tabular}{l|c|c|c|c|c|c}
\hline \multicolumn{1}{c|}{ Site } & $\begin{array}{c}\text { Age, } \\
\text { yrs }\end{array}$ & $\begin{array}{c}\text { Number } \\
\text { of } \\
\text { clones }\end{array}$ & $\begin{array}{c}\text { Crooked, } \\
\%\end{array}$ & $\begin{array}{c}\text { Straight, } \\
\%\end{array}$ & $\begin{array}{c}\text { Distinct } \\
\text { apex, } \%\end{array}$ & $\begin{array}{c}\text { Branches } \\
\text { below } \\
\text { heigt 2m, } \\
\%\end{array}$ \\
\hline $\begin{array}{l}\text { Priek/Ozolb } \\
22 \text { yrs. }\end{array}$ & 22 & 7 & no & 100 & 100 & 70 \\
$\begin{array}{l}\text { Kuld/Rumn } \\
22 \text { yrs. }\end{array}$ & 22 & 5 & no & 100 & 100 & 70 \\
$\begin{array}{l}\text { Alsunga/Zundas } \\
\text { Alsunga/Kundzini }\end{array}$ & 25 & 4 & no & 100 & 100 & 20 \\
$\begin{array}{l}\text { Edole/Berzi } \\
\text { Smilt/Vecm }\end{array}$ & 24 & 4 & no & 100 & 100 & 70 \\
Jaunpiebalga/Liede & 25 & 3 & 20 & 85 & 90 & 70
\end{tabular}




\section{DISCUSSION}

Growth rate, wood quality and appropriate pruning of sweet cherries were studied in Italy and Germany, the leading cherry timber producers. In cherry trials planted in Germany (Rhine Plain), tree height and diameter at breast hight ranged from 6.63 to $7.03 \mathrm{~m}$ and from 80 to $83 \mathrm{~mm}$ for 10 year-old trees respectively (Springmann et al., 2011). 20year-old trees grown in another trial but in the same region showed $\mathrm{H}$ and $\mathrm{DBH}$ in the range from 16 to $28 \mathrm{~m}$ and from 15 to $29 \mathrm{~cm}$, respectively (Sprengel et al., 2019). The growth rate of sweet cherries in Latvian cherry stands was strongly variable depending on site, soil properties and tending. In forest stands with optimal growing conditions, Latvian sweet cherry clones and genotypes of local origin reached a mean height of $\mathrm{H}_{\mathrm{avg}} .=15.1 \pm 1.4 \mathrm{~m}$ and $\mathrm{DBH}=$ $16.4 \pm 4.0 \mathrm{~cm}$ in 22 years. The Danish sweet cherry clone Truust 791 showed good performance in the climatic conditions of Latvia $\left(\mathrm{H}_{\mathrm{avg}} \cdot=7.9 \pm 0.6 \mathrm{~m} ; \mathrm{DBH}=10.6 \pm 2.0 \mathrm{~cm}\right.$ in 9 years). The Swedish clones No. 9 and 10 also performed well $\left(\mathrm{H}_{\mathrm{avg}}=5.2 \pm 1.2 \mathrm{~m} ; \mathrm{DBH}=7.5 \pm 2.5 \mathrm{~cm}\right.$ in 7 years). A fast growth rate was shown by a genotype with origin in north-eastern Latvia and grown in an orchard with cultivated soddy carbonate soil — the DBH reached 23.6 $\mathrm{cm}$ in 22 years.

However, it must be pointed out that the density of stocking highly differed in the above trial plantations. In a study carried out in Germany, the inter-distances of planted sweet cherry were $1.5 \times 7.5 \mathrm{~m}$ (Sprengel et al., 2019) and $1.5 \times 15$ m (Springmann et al., 2011), giving a stocking density of 888 and 444 trees/ha, respectively. In Latvia, good performance of cherry trees was observed in forest plantation with 2000 trees/ha, but the common planting pattern for vigorous sweet cherries in fruit-growing orchards was $4 \times 6 \mathrm{~m}$ or 416 trees/ha.

Density of stocking and timely pruning of branches are essential preconditions for the development of high quality stems for timber. In Latvia where the planting pattern was $2 \times 2 \mathrm{~m}$ or 2500 trees/ha, canopy closure occurred at age 5 to 6 years. The first pre-commercial thinning should be done at the age of 10 years.

The results of the given study confirmed the importance of choosing sites suitable for plantation cultivation of sweet cherry: soddy carbonate soils, cultivated soils, soddy podsolized soils, neutral or alkaline soil reaction ( $\mathrm{pH}=6$ to 7 ), and sufficient moisture througout the growing season. Careful tending and adequate protection against diseases and pests, including wildlife, are of no less importance.

Other key factor in cherry timber production is the effect of genetical properties of planting stock on growth rate and timber quality. In Italy, the effect of sweet cherry genotype on timber density was observed already for new trees and exceeded the influence of growth rate (Nocetti et al., 2012).

The research conducted thus far has shown that in order to ensure plantation cultivation of sweet cherry for wood, further work should proceed in following directions:
- inventory of forest stands and the existing first generation cherry plantations for selecting superior genotypes for propagation and determining in what season of the year the stock for vegetative propagation should be harvested;

- development of efficient techniques for rooting of cuttings;

- developing productive in vitro propagation methods and cultivating in vitro sweet cherry planting stock;

- establishing new sweet cherry plantations by using the most suitable clonal stock of the domestic and foreign origin.

\section{ACKNOWLEGMENTS}

The team of the given study owes a debt of gratitude to the LAD project 19-00-A01620-000088 "Testing the Sweet Cherry Propagation Methods and Selecting Superior Clones for Plantion Cultivation of Sweet Cherry for Timber in the Climatic Conditions of Latvia" for co-financing some of the project activies that allowed to widen the scope of research.

\section{REFERENCES}

Bert, S, Brunetti, M., Nocett, M. (2007). Product development with Italian underutilizes hardwood species. In: Proceedings of the International Scientific Conference on Hardwood Processing. Quebec, Canada, doi 10.13140/2.1.3080.0321.

Breibach, N., Laube, Steffan-Dewenter, I., Boehning-Gaese, K. (2010). Bird diversity and seed dispersal along a human land-use gradient: High seed removal in structurally simple farmland. Oecologia, 162, 965-976.

Daugaviete, M., Krūminaa, M., Dolacis, J., Hrols, J., Bērziṇa, A. (2002). Saldais kirsis (Cerasus avium (L.) Moench syn. Prunus avium L.) koksnes ražošanai: pētījumi par k̦irša izplatību, reproduktīvo materiālu, tā agrīno auǧ̌anu izmè ǵ inājumu stādījumos un daži fizikāli mehāniskie raksturielumi [Sweet cherry (Cerasus avium (L.) Moench syn. Prunus avium L.) for wood production: studies on the distribution of cherries, reproductive material, its early growth in experimental plantations and some physico-mechanical characteristics]. Mežzinātne, Nr. 12, 60-86 (in Latvian).

Daugaviete, M. (2003). Daudzmērķu kokaugu stādījumi lauksaimniecībā nerentablās zemēs [Multi-purpose tree plantations in agriculture on abandoned farmlands]. AGROTOPS, June (in Latvian).

Daugaviete, M. (2006). Ieteikumi saldā kirša (Cerasus avium (L.) Moench. syn. Prunus avium L.) sēklu avotu izvēelei, stādmateriāla audzēsanai un plantāciju ierīkošanai [Recommendations for the Selection of Seed Sources for Sweet Cherry (Cerasus avium (L.) Moench. syn. Prunus avium L.), Planting Material and Plantation Establishment]. LVMI Silava, Salaspils.18. 1pp. (in Latvian).

Daugaviete, M. (2009). Ķirsis koksnes ražošanai [Cherry for wood production]. AGROTOPS, November (in Latvian).

Daugaviete, M., Bambe, B., Lazdiṇš, A., Lazdiṇa, A. (2017). Plantāciju mežu augšanas gaita, produktivitāte un ietekme uz vidi [Plantation Forest Growth Course, Productivity and Impact on the Environment]. LVMI Silava, Salaspils. 470 lpp. (in Latvian).

Daugaviete, M., Telysheva, G., Polis, O., Korica, A., Spalvis, K. (2020). Plantation forests as regional strength for development of rural bioeconomy. In: Proceedings of the 2020 International Conference "Economic Science for Rural Development”. Jelgava, LLU ESAF, 12-15 May 2020, pp. 13-21. 
De Rogatis, A., Ferrazinzini, D., Ducci, F., Guerri, S., Carnevale, S, Belleti, P. (2013). Genetic variation in Italian wild cherry (Prunus avium L.) as characterized by nSSR markers. Orestry, 86, 391-400.

Ducci, F., De Cuyper, B., De Rogatis, A., Dufour, J., Santi, F. (2013). Wild cherry breeding (Prunus avium L.). In: Paques, L. E. (ed.) Forest Tree Breeding Across Europe. Springer, Dordrecht, pp. 463-511.

Ducci, F., Santi, F (1998). The distribution of clones in managed and unmanaged populations of wild cherry (Prunus avium). Can. J. For. Res., 27, 470 .

Feldmane, D. (2020). Izvērtētas saldo kiršu škirnes [Evaluated cultivars of sweet cherries]. AGROTOPS January, 66-68 (in Latvian).

Hawe, J., Short, I. (2016). Broadleaf thinning in Ireland: A review of European silvicultural best practice. Irish Forestry, 73, 25-64.

Hein, S., Spiecker, H. (2009). Controlling diameter growth of common ash, sycamore maple and wild cherry. Eur. J. Forest Res., 22, 123-147.

Hemedry, G., Spiecker, H., Aldinger, E. Kerr, G., Collet, C., Bell, S. (2008). COST Action E42: Growing Valuable Broadleaved Tree Species. Final report. 40 pp. http://www.valbro.uni-freiburg.de/ (accessed 14 July 2021).

Hemery, G. E., Clark, J. R., Aldinger, E., Claessens, H., Malvoti, M. E., O'Connor, E., Raftoyannis, Y., Savill, P. S., Brus, R. (2010). Growing scattered broadleaved tree species in Europe in a changing climate: A review of risks and opportunities. Int. J. Forest Res., 83 (1), 65-81.

Hubert, J., Cundall, E. (2006). Choosing provenance in broadleaved trees. Forestry Commission. Information Note. May, 2006, p. 12.

Jarni, K., De Cuyper, B., Brus, R. (2012). Genetic variability of wild cherry (Prunus avium L.) in Slovenia as revealed by nuclear microsatellite loci (2012). PLOS ONE, 7 (7), e41231.

Keris, A. (1997). Saldā kirša izplatība Latvijas Kurzemes zonas mežaudzēs [Distribution of sweet cherries in forest stands of Kurzeme zone of Latvia]. Theses of Bachelors degree in forest science. LUA. 75 pp. (in Latvian).

Kerr, G., Evans, J. (1993). Growing Broadleaves for Timber. Forestry Commision Handbook 9. HMSO, London. 95 pp.

Lacis, G., Rashal, I., Ruisa, S., Trajkovski, V., Iezzoni, A. F. (2009). Assessment of genetic diversity of Latvian and Swedish cherry (Prunus avium L.) genetic resources collections by using SSR (microsatellite) markers. Sci. Hortic., 121, 451-457.

Lange, V., Mauriňš, A., Zvirgzds, A. (1978). Dendrologija [Dendrology]. Zvaigzne, Rīga. 303 lpp.

Liepa, I. (1996). Pieauguma mācība. LLU, Jelgava. 123 lpp.

Loewe, V. M., Gonzalez, M. O., Balzarini, M. (2013). Wild cherry tree (Prunus avium $\mathrm{L}$.) growth in pure and mixed plantations in South America. Forest Ecol. Manag., 306, 31-41.

Martinsson, O. (2001). Wild cherry (Prunus avium L.) for timber production: Consequences for early growth from selection of open-pollinated single-tree progenies in Sweden. Scand. Forestry Res., 16, 117-126.

McEwan, A., Marchi, E., Spinelli, R., Brink, M. (2020). Past, present and future for industrial plantation forestry and implication on future timber harvesting technology. J. For. Res., 31 (2), 339-351.

Mangalis, I. (1998). Saldais k̦irsis (Prunus avium L.) - meža koku suga [Sweet cherry (Prunus avium L.) - a species of forest tree species]. Meža Dzìve, No. 2, 12-14 (in Latvian).

Morhart, Ch., Sheppard, J. P., Schuler, J. K., Spiecker, H. (2016). Aboveground woody biomass allocation and within tree carbon and nutrient distribution of wild cherry (Prunus avium L.): A case study. Forest Ecosyst., $3,4,2-15$.

Nocetti, M., Ducci, F., Romagnoli. M., Santi, F. (2010). Variability of wood properties in two wild cherry clonal trials. Wood Sci. Technol., 44, 621-637.

Nocetti, M., Brunetti, M., Ducci, F., Romagnoli, M., Rozenberg, P., Santi, F. (2012). Phenotypic correlations among wood properties and growth in wild cherry plantations. BioResources, 7 (3), 3160-3174.
Nocetti, M., Brunetti, M., Ducci, F., Romagnoli, M. (2017). Wood characterization of clones selected for valuable timber production: the case study of Italian wild cherry.

http://www.valbro.uni-freiburg.de/pdf/pres_italy/wood_characterization_ of_clones.pdf (accessed 14.07.2021).

Oz, E. (2020). Effects of smoke flavoring using different wood chips and barbecuing on the formation of polycyclic aromatic hydrocarbons and heterocyclic aromatic amines in salmon fillets. PLOS ONE, 15 (1), e0227508.

Pakenham, R. (2005). Growing valuable broadleaved tree species: Silvicultural perspective. Presentation given in Thessaloniki, $18^{\text {th }}-21^{\text {st }}$ May 2005. http://www.valbro.uni-freiburg.de/pdf/pres_thes_grow.pdf (accessed 14.07.2021)

Payn, T., Carnus, J. M., Freer-Smith, P., Kumberley, M., Kollert, W., Liu, Sh., Orazio, C. H., Rodriguez, L., Silva, L. N., Wingfield, M. J. (2015) Changes in planted forests and future global implications. Forest Ecol. Manag., 352, 57-67.

Pavlovičs, G. (2011). Research of Latvian innovative furniture and construction material from sweet cherry (Prunus avium L.) wood properties. Summary of the Doctoral Thesis. Rīga. 27 pp.

Pavlovičs, G., Dolacis, J., Alksne, A., Cīrule, D., Hrols, J., Daugaviete, M., Blaho, J. (2007). Saldā kirša (Prunus avium L.) koksnes anatomisko un fizikāli - mehānisko ìpašību pètījumi [Investigations of anatomical and physical-mechanical properties of sweet cherry (Prunus avium L.) wood] . LLU Raksti. Vol. 18. Jelgava, 77.-80. 1pp. (in Latvian).

Petrokas, R. (2010). Perequisites for the reproduction of wild cherry (Prunus avium L.). Baltic Forestry, 16 (1), 139-150.

Pollmann, B., Jacomet, S., Schlumbaum, A. (2005). Morpphological and genetic studies of watterlogged Prunus species from the Roman vicus Tasgetium (Eschanz, Switzerland). J. Archeol. Sci., 32, 1471-1480.

Praciak, A. (2013). The CABI Encyclopedia of Forest Trees. CABI, Oxfordshire, UK. $536 \mathrm{pp}$.

Pryor, S. N. (1988). The Silviculture and Yield of Wild Cherry. Forestry Commission. Bulletin 75. London. 28 pp.

Regnell, M. (2012). Plant substistence and environment at the Mesolithic site Tågerup, southern Sweden: New insights on the "Nut Age". Veget. Hist. Archaebot., 21, 1-16.

Ruisa, S. (2015). Saldie un skābie kirši [Sweet and Sour Cherries]. Latvijas Mediji. 118 1pp. (in Latvian).

Rushforth, K. (1999). Trees of Britain and Europe. Collins. 1336 pp.

Russel, K. (2003). EUFORGEN Technical Guidelines for Genetic Conservation and Use for Wild Cherry (Prunus avium). International Plant Genatic Resources Institute, Rome. 6 pp.

Santi, F., Muranty, H., Dufour, J., Paques, L. E. (1998). Genetic parameters and selection in a multisite wild cherry clonal test. Silvae Genetica, $\mathbf{4 7}$ $2-3$.

Savill, P. S. (2013). The Silvicvilture of Trees Used in British Forestry. CAB International, Wallingford. $384 \mathrm{pp}$.

Short, I., Radford, T. (2008). Silvicultural Guidelines for the Tending and Thinning of Broadleaves. Teagasc.

Sprengel, L., Stangler, D. F., Sheppard, J., Morhart, C., Spiecker, H. (2018) Comparative analysis of the effects of stem height and artificial pruning on seasonal radial growth dynamics of wild cherry (Prunus avium L.) and Sycamore (Acer pseudoplatanus L.) in a widely spaced system. Forests, $\mathbf{9}$, 174.

Springmann, S., Rogers, R., Spiecker, H. (2011). Impact of artificial pruning on growth and secondary shoot development of wild cherry (Prunus avium L.) Forest Ecol. Manag., 261 (3),764-769.

Stojecova, R., Kupka, I. (2009). Growth of wild cherry (Prunus avium L.) in a mixture with other species in a demonstration forest. J. Forest Sci., 55, 264-269. 
Turnbull, J. W. (2009). Tree Domestication and the History of Plantations. The Role of Food, Agriculture, Forestry and Fisheries in Human Nutrition. Vol II. Encyclopedia of Life Support Systems. https://www.eolss.net/Sample-Chapters/C10/E5-01-02-02.pdf (accessed 14.07.2021).

Velioglu, E., Alan, M., Atmaca, C., Tastan, Y., Uzan, B. (2020). Estimation of genetic parameters for soe quantitative trait of Prunus avium L. in Turkey. Turkish J. Forestry Res., 7 (2), 179-192.

Received 4 January 2021

Accepted in the final form 22 July 2021
Welk, E., de Rigo, D., Caudullo, G. (2016). Prunus avium in Europe: Distribution, habitat, usage and threats. In: San-Miguel-Ayanz, J., S.M., de Rigo, D., Caudullo D., Houstan-Durant, T. Mauri, A. (eds). European Atlas of Forest Tree Species. Publ. Off. EU. Luksembourg.

Zianis, D., Muukkonen, P., Makipaa, R., Mencuccini, M. (2005). Biomass and Stem Volume Equations for Tree Species in Europe. SILVA FENNICA Monographs 4. Finnish Society of Forest Science, Finnish Forest Research Institute, Helsinki. 63 pp.

SALDĀ KIRŠA (PRUNUS AVIUM L. SYN. CERASUS AVIUM MOENCH.) IZPLATĪBAS PĒTĪJUMI, PERSPEKTĪVĀKO KLONU

Izmēǵinājumi liecina, ka saldā ķirša plantāciju meža stādījumi prasa piemērotas augšanas vietas izvēli: velēnu karbonātu, kultūraugsnes, velēnu podzolētas augsnes ar neitrālu vai sārmainu reakciju $-\mathrm{pH}=6-7$, kuras ir nodrošinātas ar pietiekamu augsnes mitrumu visā veğetācijas periodā, kā arī rūpīgu kopšanu un aizsardzību gan pret kaitēkḷiem, gan pārnadziem. Labvēlīgos augšanas apstākḷos 22 gadu

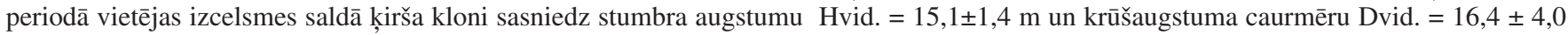
cm. Būtisks nosacījums kvalitatīvu saldā kirša stumbru veidošanai ir gan atbilstošs stādījuma biezums, gan savlaicīga stumbru atzarošana. Stādījumos pie stādīšanas shēmas $2 \times 2$ m vai 2500 koki/ha vainagi saslēdzas 5-6 gadu vecumā. Pirmā krājas kopšana jāveic 10-gadīgos stādījumos. Labus augšanas gaitas rādītājus uzrāda saldā ķirša Dānijas klons Truust 791, vidējais koku augstums 9-gadīgā stādījumā sasniedzis Hvid. = 7,9 0,6 m un krūšaugstuma caurmēru D1.3 = 10,6 2,0 cm. Kā arī Zviedrijas kloni Nr. 9 un Nr. 10, kurā augsanas gaita rādītāji attiecīgi ir: Hvid. $=5,2 \pm 1,2 \mathrm{~m}$ un D1.3 $=7,5 \pm 2,53 \mathrm{~cm}$.

Līdzšinējie pētījumi liecina, ka kvalitatīvu saldā ķiř̌a plantāciju izveidei koksnes ražošanai, nepieciešams veikt turpmākos pētījumus sekojošos virzienos:

- 1. pakāpes saldā ķirša plantāciju un mežaudžu apsekošana un perspektīvu klonu atlase veǵetatīvai pavairošanai piemēroto daḷu ievākšanas laika noteikšana,

- produktīva spraudeņu apsakṇošanas metodes izstrāde,

- produktīva mikroklonālās pavairošanas metodes izstrāde un stādu izaudzēsana,

- saldā ķirša perspektīvo vietējās izcelsmes un citzemju klonu stādījumu ierīkošana turpmākai produktīvu saldā kirša plantāciju ierīkošanai. 